Island Studies Journal, Vol. 4, No. 1, 2009, pp. 53-84

\title{
Geography, Islands and Migration in an Era of Global Mobility
}

\author{
Russell King \\ Department of Geography and Sussex Centre for Migration Research \\ University of Sussex \\ United Kingdom \\ R.King@sussex.ac.uk
}

\begin{abstract}
This paper examines the changing role of islands in the age of globalization and in an era of enhanced and diversified mobility. There are many types of islands, many metaphors of insularity, and many types of migration, so the interactions are far from simple. The 'mobilities turn' in migration studies recognizes the diversification in motivations and time-space regimes of human migration. After brief reviews of island studies and of migration studies, and the power of geography to capture and distil the interdisciplinarity and relationality of these two study domains, the paper explores various facets of the generally intense engagement that islands have with migration. Two particular scenarios are identified for islands and migration in the global era: the heuristic role of islands as 'spatial laboratories' for the study of diverse migration processes in microcosm; and the way in which, especially in the Mediterranean and near-Atlantic regions, islands have become critical locations in the geopolitics of irregular migration routes. The case of Malta is taken to illustrate some of these new insular migration dynamics.
\end{abstract}

Keywords: geography, globalization, interdisciplinarity, island studies, islands, Malta, migration, mobility

(C) 2009 - Institute of Island Studies, University of Prince Edward Island, Canada.

\section{Introduction}

Geography; islands; migration: a trio of academic fields which not only define in large measure the author's own personal scholarly biography but also interlock in a triangle of creative interdisciplinarity. Islands - areas of land surrounded entirely by sea - are an obvious geographical entity, unique spaces within the world's geography. Migration human movement across space to live 'elsewhere' - is a process which is quintessentially geographical. Geography, then, is perfectly placed to capture the interdisciplinarity and relationality of these two relatively new fields - island studies and migration studies. Simultaneously a science, social science and a humanities subject, geography is the broadest of disciplines. Indeed, perhaps it is a misnomer to call it a discipline; I would call it an 'interdiscipline'.

Islands and migration: what are the scales of the two phenomena under study? According to Baldacchino (2007: 1), some 600 million people, 10 per cent of the world's population, live on islands; and islands, including archipelagos, make up one quarter of the world's sovereign states. On the migration front, extrapolating from the latest estimates from the 


\section{R. King}

UN Population Division, there are 200 million international migrants in the world; that is to say, people currently residing in a country which is different from that of their birth. However, if migration within countries is included, the figure rises many-fold, but there are no global figures on internal migration.

This paper, then, is about the relations between islands and migration, seen from a geographer's broad and interdisciplinary perspective. It is in six parts. First I say something about geographers' engagement with the study of islands, which reflects the fact that most geographers regard islands as 'special' places with distinctive characteristics. At the same time, studying islands carries with it certain risks of escapism and of lack of serious commitment to the 'big picture' of world geography. Next I review in turn the two interdisciplinary fields of island studies and migration studies. Then I bring them together in a series of interactions and interfaces. Islands have nearly always had an intense involvement with migration; but the nature of this engagement, and the types and sequences of migration that result are linked to the diverse historical roles that islands have played. In the following part of the paper I develop two scenarios for island-based migration research: islands as strategic sites in the new geography of irregular migration routes, especially between Africa and Europe; and islands as spatial microcosms for the analysis of multiple migration processes and effects. The final section of the article takes Malta as an illustration of the two scenarios; Malta being an ideal case both because of the mix of different types of migration it has experienced, and because of its new role, connected with EU accession in 2004, of being on the front line of the arrival of boatmigrants from North Africa.

\section{Geographers and Islands}

Islands have long attracted the attention of geographers (King, 1993). Particularly notable are the early-twentieth-century writings of the French geographers Jean Brunhes (1920) and Paul Vidal de la Blache (1926), continued later by the geo-historian Fernand Braudel whose magisterial treatise on the Mediterranean speaks at length on the special role of islands in Mediterranean economic, social and cultural history (Braudel, 1972: 148-167). Brunhes (1920: 52) saw islands as "little geographical worlds" wherein "by careful study of a small unit one can discern and evaluate the relations between physical facts and human destinies". Ellen Churchill Semple, notorious for her controversial philosophy of environmental determinism, also wrote copiously about 'island people' in her book Influences of the Geographic Environment. She described islands' proneness to emigration: "A small cup soon overflows... herein lies [islands'] historical significance" (1911: 416).

These early writings, products of their time, opened up important geographical perspectives on island studies - the concept of insularity, the special characteristics of island populations (including what we would call today their identity), pioneering ecological analyses, the historical dialectic between isolation and focalism, and cycles of landscape change due to colonialism and settlement, emigration and depopulation. 
Later in the last century, islands became less fashionable as objects of geographical study. As geography went robustly through its normative, model-building, theory-seeking stage, the emphasis was on grand (but often abstract) generalizations. Islands fell off the map of geographical enquiry. In fact, five problems seemed to confront geographers (and others) studying islands, and these issues are still relevant today.

- Islands equate holidays, relaxation and having a nice time, not serious scholarship. When I tell my colleagues (even the geographers) that I am going to Malta and Cyprus (the two islands where I am currently conducting some research), or to the Azores for an international conference, they smile knowingly as if to say "Oh yeah?" I insist: there is no contradiction.

- The smallness of islands denotes insignificance; there are no 'big questions' on small islands, which are regarded as "irrelevant backwaters" and "somehow unimportant" (Hay, 2006: 21; Lowenthal, 1992: 18). But geography is not about size, or the built-in assumption that large spaces are more important than small ones. No, geography is about spaces and places at different scales, about relationships between the global and the local, and about spatial relations and connectivities (including, of course, migration) in which small islands are deeply embedded and have their place in the global-local nexus (Baldacchino, 2005: 248; Ratter \& Sandner, 1996: 64).

- Studying islands invokes an academic colonial gaze - the outsider, 'the expert', looking in. Baldacchino (2007: 2-3) calls this "islanding" (cf. 'othering'): "a removal of agency, cheating islanders of the possibility of defining themselves and of articulating their own concerns and interests". Thus academics, in acquiring and possessing the knowledge of the island, contribute yet another layer to islands' histories of colonialism, whose most active agent today is probably tourism ${ }^{1}$. Grant McCall's plea that islands should be studied on their own terms (1994, 1996) suggests an escape from academic colonialism and a process of empowerment in which islanders frame the research agenda and become active partners in the research process. However, McCall's manifesto carries its own dilemmas, as we all shall see presently.

- The fallacy of regarding islands as small-scale models of the wider world. Brunhes (1920: 499) wrote that island studies were the first regional monographs; such comprehensive studies of "little worlds of humanity" pioneered the regional method in geography, leading to larger-scale studies of less definable mainland territories. Brookfield counters: "the common trap with island studies [is] of assuming that all islands are in some way a microcosm of the larger world. They are not" (1990: 31). There is, however, a middle way. Islands can be studied with rigour, both for themselves, as geographical entities (like mountains, deserts, cities... ), and as places where, under relatively controlled conditions, the interrelationships between the island environment, histories of development and underdevelopment, population and

\footnotetext{
${ }^{1}$ Of course, colonialism, tourism and academia cannot be equated in such a straightforward way. True, they all entail an outsider's gaze, but the rationales and means of appropriation are very different.
} 
migration, can be studied in sharper focus. Herein lies the heuristic value of islands for geography.

- The danger of exceptionalism - of regarding islands as too special, too unique. This is the other side of the coin of the previous issue. Here we are faced with an essentialism of 'islandness' on the one hand, and on the other a blinkered myopia on the part of scholars about 'their' particular island which is somehow regarded as different from all others. This can be overcome both by 'horizontal' comparative studies with other islands, and by 'vertical' integration of islands within hierarchies of regional and global relations.

\section{Island Studies}

Baldacchino (2004) has proclaimed the "coming of age" of island studies; but the essence of island studies remains both obvious and elusive. This reminds me of the old debate about the definition of geography, which often fell back on the tautalogous definition "geography is what geographers do". And "what do geographers do?" "They study the world". So it could be for islands. "What is island studies?" "It's the study of islands." What do island studies scholars study on islands?" "Everything". This implies a 'Jack-ofall-trades' approach of the combined geographer, ecologist, geologist, anthropologist, sociologist, economist and historian, enabling island studies to be "the critical, inter- and pluri-disciplinary study of islands on their own terms" (Baldacchino, 2007: 16).

Let me now head off at a bit of a tangent. Island studies seems to be a male domain (hence my use of 'Jack' above was deliberate), in contrast to migration studies which has become feminized, as we shall see below. Despite (or indeed because of) the fact that islands themselves, with their images of tropical climates and swaying palms, are often perceived as 'she'/female, islands are objects predominantly of the male gaze, to be studied, objectified, collected and possessed. I know island aficionados (males, of course) whose islophilia involves visiting as many islands as possible, ticking them off the list, and collecting the T-shirt to prove they have 'been there'. Baldacchino (2007: 3-4) comments on the desire of the (almost inevitably male) visitor to circum-navigate the island, climb triumphantly to its highest point to 'take it all in', even to sing and shout. According to Hay (2006: 27) islands connect with metaphors of western masculinity, as well as literary classics ranging from Robinson Crusoe (Defoe 1719/1980) to D.H. Lawrence's The Man who Loved Islands $(1926 / 1982)^{2}$.

More prosaically, McCall $(1994,1996)$ has proposed the term nissology for "the scientific study of islands on their own terms". Along with Baldacchino (2008a), I detect an inherent contradiction in this definition. McCall favours the islanders' own emic perspective over

\footnotetext{
${ }^{2}$ Recently, I reviewed Baldacchino's A World of Islands (see King, 2008). The first few pages of the book are taken up by pictures of the book's 23 main contributors - all but four are male, middle-aged or elderly and often bearded. Of course, I too fit that identikit! Another observation from the photo-gallery is that all authors are 'white', which certainly does not reflect the ethno-racial composition of the world's island populations, but reinforces the Western, 'colonial' gaze of island-studies scholars.
} 
the etic gaze of the outsider, but two problems arise. First, "scientific study" implies a set of orthodox research strategies which may override the islanders' own view. Second, the division between islanders and non-islanders, insiders and outsiders, is not so clear-cut. Given islands' long histories of migration, both in and out, who is an islander? What, therefore, is meant by "on their own terms"? Such a construction implies homogeneity and agreement within island communities, and overlooks divisions based on class, ethnicity or migration history.

Another approach to island studies is through the notion of 'islandness' (Baldacchino, 2004: 272-274), the key characteristics of which are usually listed as smallness, a strong sense of local or island culture and identity (typically implying some tension with a larger 'mainland'), peripherality, and a sense of being bounded by water. But parts of this framing of islands project a too-negative image, as Baldacchino himself acknowledges. The term 'insularity' carries problematic connotations of isolation and inward-lookingness, whereas many islanders are very outward-looking, by their very nature as islanders. Peripherality is both relative and subject to change, as well as being multi-dimensional. Taking Europe as an example, the economic geography of core and periphery under one system (the Fordist model, for instance), may become partially inverted under another economic model, based on tourism, light industry and financial services. The 'Celtic Tiger' economy of Ireland is a case in point, propelling the country within a decade from a relatively poor status (by European standards) to one of the continent's most prosperous and dynamic member-states. Or consider Ibiza: transformed from a rural, semi-subsistence economy to the youth tourism clubbing capital of Europe.

A third angle on island studies which is quite prominent, especially in the geographical literature, is the 'spatial laboratories' approach, the dangers and possibilities of which I noted earlier, including the fallacy of regarding islands as miniature replicas of the mainland or as closed systems. Nevertheless islands have long been productively utilized as a semi-laboratory setting for the study of ecological, epidemiological and social processes, including migration (Connell \& King, 1999; King, 1999).

As regards migration, two further approaches to islandness are especially relevant economics and demographics. There is now an extensive literature on the economic and developmental problems of small islands, some of which overlaps with economic analyses of small states (see, inter alia, Baldacchino \& Greenwood, 1998; Baldacchino \& Milne, 2000; Bertram \& Poirine, 2007; Biagini \& Hoyle, 1999; Briguglio, 1995; Connell, 1988; Dommen \& Hein, 1985; Hintjens \& Newitt, 1992; Lockhart et al., 1993). Undoubtedly, smallness and insularity bequeath a range of economic handicaps ${ }^{3}$ : the small size of the local market for goods and services; the limited range of island products due to the narrow resource base; high transport costs for both exports and imports; vulnerability to world market prices; risk of crop failure due to exposure to natural disasters such as drought, hurricane or diseases; and the limited or 'truncated' local labour market with few opportunities for highly educated or ambitious young people. Emigration often becomes

\footnotetext{
${ }^{3}$ There is a danger of conflating smallness and insularity: the two are not always related. Ireland, Britain and Australia are all associated with narratives of insularity, island identity and 'island race', yet they are far from small.
} 


\section{R. King}

the response to these economic vulnerabilities; labour becomes the 'monocrop' to be exported to the global market, as Schneider and Schneider (1976) showed in the context of western Sicily, where workers replaced wheat as the major export product. Especially for smaller islands, the end-result is often the MIRAB economic model, whereby migration, remittances, aid and bureaucracy are the key parameters (Bertram \& Watters, 1985; for updates see Bertram, 2006; Bertram \& Poirine, 2007).

But this is not the whole story. Islanders' supposed condition of poverty and economic vulnerability is countered by the fact that island states' GDP per capita is above the world average, and small island states are disproportionately numerous amongst higher and upper-middle income countries (Read, 2004). The economic riddle is solved by islands' skills in identifying high-income-earning niche products and services in the global economy, trading on the economic nimbleness which is perhaps easier to exercise from a small-scale jurisdiction (Bernard \& Poirine, 2007). Islands thus exemplify post-industrial spaces where flexible specialization is the watchword and where a higher level of connectivity to the global system can be capitalized upon. Tourism, including niche tourism, and financial services, especially offshore banking, seem to be the key sectors for many islands' prosperity, although such activities are, in turn, not without their risks and limits. Tourism and banking are themselves subject to market volatility, and not every island is equipped climatically for tourism, or knowledge-wise for financial industries. Tourism in particular brings its own problems of seasonality, disruption of island lifestyles, external ownership and environmental pressure - there is extensive literature on these issues (e.g. Apostolopolous \& Gayle, 2002; Briguglio et al., 1996a, 1996b; Gössling, 2003; Gössling \& Wall, 2007; Lockhart \& Drakakis-Smith, 1997).

The final analytical field within island studies - one which has a close bearing on migration - is the socio-demographic perspective. Many small islands evolve relatively homogenous and intimate societies with a strong sense of common identity. Everyone knows everyone else, at least as an acquaintance or through common friends, and there is an equally close knowledge of the local environment - every house, every field, every track, every beach is known and recognized ${ }^{4}$. Population growth may stretch this equilibrium in various ways, leading ultimately to out-migration. Pressure on the land, meantime, can provide the stimulus to construct elaborate terrace systems, seen in various parts of the world: in Java for instance where the progressive increase in the population led to a parallel intensification of the agricultural ecosystem with spectacular rice terraces and minutely managed irrigation systems, a process called by Clifford Geertz (1963) agricultural involution. Elaborate terraces for vines and other crops are also found throughout the Mediterranean and Macaronesian archipelagos; perhaps most spectacularly on Madeira. Eventually, the demographic momentum may overshoot, projecting the population beyond the island's carrying capacity at the level of technology and economic resources that the island possesses at the time, and emigration results. This leads to new cycles of demographic, social, economic and landscape change which have been copiously analysed in the literature on island migrations (for overviews see Connell, 2007; Connell \& King, 1999; King 1999). Return migration may cushion the long-term demographic and

\footnotetext{
${ }^{4}$ This condition, one must acknowledge, also applies to villages, studied through the classic anthropological condition of the 'small-scale'.
} 
economic decline somewhat, but much depends on the age of the returnees and the financial and human capital they bring back.

\section{Migration Studies}

One of the justifications for the 'coming of age' of island studies as a recognized academic field is the existence now of two MA programmes (at the University of Prince Edward Island and the University of Malta) and three dedicated journals, the peer-reviewed Island Studies Journal, which started in 2006, Shima: The International Journal of Research into Island Cultures, started in 2007, and the longer-established (since 1992) but less academic Insula, published with the support of UNESCO (Robertson, 2007: 576-577).

On these criteria, 'migration studies' is an older and more broadly established interdisciplinary field. The first MA in Migration Studies started at the University of Sussex twelve years ago, and there are many such programmes now, especially in Britain and Europe, including some specialized masters' such as Oxford's MSc in Refugee Studies. The three leading journals in the field - International Migration, International Migration Review and the Journal of Ethnic and Migration Studies - have been running since 1962, 1966 and 1974 respectively. New journals are founded every year, it seems, one of the latest and most interesting being Mobilities, launched in $2006^{5}$.

The literature on migration studies is truly vast and growing exponentially. Following my approach in the previous section, I signpost some key themes and perspectives.

Migration is usually defined as the movement of people from one place or country to another, for a significant period of time such as more than one year. It is, thus, both a spatial event and a temporal one; but also to some extent an artifice of the spatio-temporal thresholds that have to be crossed for migration to be said to have taken place. For the statistical measurement of migration, boundaries have to be crossed (international frontiers, or internal administrative boundaries such as provinces or municipalities), and certain time(s) elapsed before the move is 'registered'. Hence the measurement of migration is far from uniform across the world. Thresholds are arbitrary and open to different interpretations in different places. In the United States, for instance, a move from one street to another within a city, or from one rural area to another within a county, might not be conventionally regarded (or statistically recorded) as migration; it might instead be called 'residential relocation'. Time, too, is arbitrary and situation-dependent when it comes to migration. The one-year criterion noted above - which is commonly used by migration scholars and national and international statistical agencies - leaves out seasonal migrations whose movement regimes are more short-term but no less significant, both to the individuals concerned and in terms of their contribution to the overall map of global human mobility.

Although migration has been a constant feature of humankind throughout history (King, 1996, 2007), the academic study of migration really only started with the industrial age

${ }^{5}$ Others are the Journal of International Migration and Integration (2000), Journal of Immigrant and Refugee Studies (2003), and Migrations and Identities (2008). 


\section{R. King}

(Boyle et al., 1998: 59). It was the geographer Edward Ravenstein who made the foundational statement about migration studies in his famous 'laws of migration' (1885, 1889), still widely referred to today. Ravenstein's eleven laws - which are really empirical generalizations rather than laws sensu strictu - showed migration to be essentially economically driven, both in terms of individuals' motivation and with regard to the relative levels of development of sending areas (poor, rural, with limited opportunities) and the receiving contexts (urban, industrial, commercial, and with more opportunities). One of his laws - that females are more migratory than males, particularly over shorter distances passed almost unnoticed at the time but has been shown to have special relevance in recent years. I refer here to the feminization of migration, by which I mean three things. First, females make up an increasing share of total migrants. Nowadays, females comprise almost exactly half (49\%) of all international migrants: although, to be fair, and this was Ravenstein's point, females have always been prominent in migration streams (it was simply that they were 'ignored' by theories and narratives which constructed migration as a 'male' process). Secondly, women have increased agency in migration; that is to say they are increasingly migrating independently of men and often as leaders of migration chains. This is in contrast to the past where they were more likely to be (constructed as) 'followers' or 'accompaniers' of the 'pioneering' male migrants. And thirdly, the study of migration has become feminized. Whilst it is true that the older generation of migration scholars (like island studies scholars) remains resolutely male-majority, amongst younger researchers there is a distinctive majority of females. In contrast, then, to the masculinist gaze of island studies, the study of migration is increasingly, and predominantly, carried out by (young) women ${ }^{6}$.

Of course, there is much more that could be said about migration; far more than can even be hinted at here. Let me just make a few key points. Following Castles \& Miller (2003: 21), I make a distinction between the act of migration, and migration's consequences; or between causes and effects. This has special relevance to islands where the causes and consequences of migration may be clearly separated in space and time. Causes embody several fundamental questions. Why do people migrate? Who migrates? And where do they move to? The effects fall into two groups: impacts of migration on the places/islands 'left behind' (depopulation, demographic distortion, brain drain, loss of labour etc.); and the formation of migrant communities in the places of destination (such as the preservation of 'island identity', integration into the 'host society', and possible return 'home'). However, the separation between causes and consequences is not absolute. Consequences can become causes, for example when depopulation (an effect) causes further outmigration because of the declining market base for economic activities, or declining morale. Likewise, the return to the island of 'successful' migrants can act as a stimulus to further migration through the 'demonstration effect'.

\footnotetext{
${ }^{6}$ Here is some anecdotal statistical evidence to support this statement. Of the twelve years' worth of students I have taught on the Sussex MA in Migration Studies (around 150 students in all), nine out of ten have been female. I also acknowledge that this trend is part of a progressive feminization of higher education in the UK and many other countries.
} 
'Cause' and 'effect' is only one of a number of binaries which dissect the study of migration. In practice, these dichotomies are often blurred, as the following examples show (King, 2002).

Forced vs. voluntary is a common division in migration studies, used particularly to address the distinction between refugees and so-called 'economic migrants'. In recent years the latter term has come to have a negative connotation in the media and in political rhetoric (especially in the UK), and has become infused with implications of 'illegality' and 'bogus' asylum claims (Kaye, 2001). Of course, there are migrations which are easily classifiable either side of this binary. The forced evacuation of the population of Diego García in the Indian Ocean to make way for a US military base is an obvious example (Vine, 2004). Equally clear-cut as an instance of voluntary migration is the 'retirement migration' of older British and German citizens to islands such as Majorca and Tenerife (Casado-Díaz et al., 2004). But a great deal of migration that takes place in the world lies between these two extremes and blurs the forced/voluntary divide. The history of migration from many Caribbean islands, especially in the early post-war decades, is a good illustration. Migrants were not coerced to leave as such, but were, in effect, driven to emigrate by powerful economic imperatives. For the poor and unemployed, emigration was the only 'way out' of destitution and the only route to achieve a measure of well-being.

A further important dichotomy is that between internal and international migration. As Skeldon (2006: 16-17) points out, these amount to "two migration traditions" based on different datasets, theoretical assumptions and analytical methods, producing different literatures and linked to different policy arenas. Yet this dichotomy is, in practice, blurred - for instance when the same migrant moves both internally and then internationally (or vice-versa), or when boundaries change, so that former internal migrants become international migrants (as in Yugoslavia before and after the creation of new independent states in the 1990s).

Introducing the island dimension further complicates, but also illuminates, this division of scale and type of migration. Imagine an archipelago made up of larger and smaller islands, not an independent state but part of a country whose main territory is a 'mainland': the Azores is a good example. The following scale hierarchy of migrations may be observed:

- $\quad$ intra-island migration - especially on a large island like São Miguel, there will be local-scale migrations from remote villages or hamlets to the capital Ponta Delgada and other main towns;

- inter-island migration - for instance from smaller islands like Santa Maria or Graciosa to larger ones such as São Miguel or Terceira;

- migration to the mainland - this is still internal migration within the same country (Portugal) but may involve considerable distances and 'dislocations';

- migration to another country - this could either be on the same continental mainland as the country to which the archipelago belongs (i.e. another European country such 
as France - actually this is not an important destination for Azoreans although it has been for Portuguese emigrants), or another country in another continent (in the Azorean case, most emigration has been to the United States and Canada, plus some other countries such as Brazil and Bermuda).

Once again, we need to acknowledge that these migration trajectories are not necessarily mutually exclusive alternatives but can be combined in an individual's migratory biography in various sequences, perhaps interleaved by return migration(s), or they can be experienced by different members of the same family. Nor is the above list an exhaustive typology: reverse migration flows, such as return from abroad, or the movement into rural island spaces of dissatisfied urban refugees, are also part of the migration dynamics.

Finally, to bring this briefest of overviews of migration studies up to date, two new paradigms have coursed through the field over the past 15-20 years. Both reflect the broader phenomenon of globalization and its effect on mobility and identity. The first is the transnationalist approach (see Basch et al., 1994 for the definitive study), which has, to some extent, rejuvenated the older tradition of diaspora studies (Vertovec \& Cohen, 1999). Transnational migrants are immigrants who engage in regular and sustained activities linking them back to their homeland. It is not enough to be an international migrant to be transnational: the key criterion is that transnational activities (sending remittances, making return visits, supporting hometown associations, trading goods, close communication with kin back home etc.) are a central part of a migrant's life. With their usually strong islander identity, it is often the case that island-origin emigrants have strong transnational identities, although translocal might be a better descriptor. As the title of one of my co-edited books indicates, island migrants come from 'small worlds' yet lead 'global lives' (King \& Connell, 1999). Their global lives are rooted in the small place that is 'their' island, whose community they still see themselves part of, even if their returns are sporadic or negligible (Felgentreff, 1999). As a popular Azorean saying goes, "Azoreans always carry their island on their backs" (Williams \& Fonseca, 1999: 67). And it is no accident that some of the pioneering studies of transnational migrants in the US are based on islander migrants, notably Dominicans and Haitians (see Glick-Schiller \& Fouron, 1998; Guarnizo, 1994, 1997; Itzigsohn et al., 1999).

The second, and more recent, new paradigm in migration studies is the 'mobilities turn' (Sheller \& Urry, 2006; Urry, 2000) which not only stresses the defining role of mobility in postmodern societies but also frames migration as one of a continuum of mobility types, including travel, tourism, circulation, sequential migration, and virtual mobilities. Urry (2000) and Beck \& Beck Gernsheim (2002) argue that what characterizes global society, and especially the more advanced societies of the world today, is not the old 'fixed' categories of class, residence, career-based employment, family and kinship, but rather individualization and mobility. People increasingly story their lives not so much as who they are, what they do and where they live, but recount where they have been and where they want to go. Thus, alongside the recognized 'forms of capital' - financial, human, social, cultural (Bourdieu, 1986) - we can now consider mobility capital. Islands feature prominently in these new 'mobilityscapes', both as origins (islanders who want to leave, 
'see the world' and return) but more especially as destinations for tourism, travel, escapism, 'dropping out', 'moving in and moving on', and so on.

Like other forms of capital, the distribution of mobility capital is highly uneven. How people deploy their mobility capital depends on whether they are rich or poor, and on where in the world they were born and hence what 'mobility rights' they have. It is an irony that, in this supposedly globalized world of free movement (of goods, capital, ideas, and so on), one of the key factors of production - labour, people - is subject to draconian regimes of migration control. Or rather, certain categories of people (the wealthy, those from 'the West', people of certain ethnicities) are free to migrate, whereas others are not (the poor, the uneducated, people of colour, from the less developed world). This polarization in access to mobility seems to be getting worse, so that there is an increasing gap between the aspiration to migrate and the ability to do so (Carling, 2002). Castles \& Miller (2003) write that we live in "the age of migration", but this need to be qualified: an age of migration for some, but not for others.

\section{Migration and Islands}

I rack my brains and I cannot recall any definitive study of migration from an island where the island dimension is central to the study. (Of course, there have been very many studies of migration from islands, but none are truly canonical). If we look at accounts of the history of migration, we find them dominated by the so-called 'great migrations' - of slavery, indenture, colonial settlement, labour migration (King, 1996). Islands have been involved in all these but are not a key part of the grand narrative.

Yet there is no doubt that islands have nearly always had an intense engagement with migration - settled by migration in the first place and often deeply affected by migration thereafter. The rates and indices of migration on islands - especially as regards emigration/outmigration - are certainly higher than 'mainland' countries or regions (even if no-one has made the exact calculations). The intensity, types and chronological sequence of migration depend on the historical roles that islands have played. In a previous essay (King, 1999) I drew a simple contrast between two historical roles: islands as marginal spaces, and as nodal places. Nodal islands tend to attract and exchange population, leading to the creation of cosmopolitan, hybrid and stratified societies, often with an 'open' mentality towards the outside world. Marginal islands tend eventually to become areas of outmigration and depopulation, leading to the MIRAB syndrome described earlier.

But marginal vs. nodal is a too-simplistic dichotomy of islands in the current global scenario. Bertram \& Poirine (2007) show that the smaller and more isolated the island, the greater the need to be open to the world market and to specialize in a narrow set of revenue-generating activities. For successful small-island economies, the keywords are specialization and flexibility; especially the ability to make rapid switches to new and profitable specialized economic niches. Bertram \& Poirine (2007: 333-335) point to the rapid shift of the Cayman Islands from a classic MIRAB economy to a financial services and tax haven powerhouse within a decade. Hence the Cayman Islands have virtually no 


\section{R. King}

emigration and, instead, attract in-migrants and visitors from near and far (Connell, 1994). These authors demonstrate that the economic vulnerability index (a measure of the narrow range of economic activities), based on data from 69 island economies, is positively not negatively correlated to per capita income.

Warrington \& Milne (2007) proffer a more sophisticated typology of islands, based on governance and historical relationship to the 'world system'. Below, I follow their sevenfold typology, making connections to different histories of migration. These types are by no means mutually exclusive, and certain islands can fulfil different roles at different points in their history, or exhibit a combination of roles simultaneously.

First come islands of civilization, of which, in modern times, there are just two, Britain and Japan, both large archipelagic countries. Through trade and conquest, these islands have generated global economic and cultural power, and an insular autonomy and hegemony that are the very antithesis of the vulnerability so often regarded as typical of islands. Linked to their imperial political and economic projects, these islands' migrations are those of colonial and trading settlement. Later, especially in the case of the UK, labour inmigration from the (former) colonies and other poor countries becomes characteristic, driven by the demands for labour that a highly prosperous capitalist society generates.

Next we have islands of settlement: these are settler colonies which are recipients of the colonial migrants referred to immediately above. For Britain, they were, above all, the 'white dominion' islands of New Zealand and the island-continent of Australia. Iceland is another example, from another imperial realm. Their role has been one of thinly populated territories capable of absorbing surplus population from the colonial homeland, mainly through voluntary and often sponsored and subsidized migration.

Third are plantation islands, also a product of the colonial era, but this time as more subordinate elements, supplying a narrow range of commodities to the imperial homeland. Typical plantation products were sugar, cotton, coffee, tea, spices and valuable minerals. This hyper-specialization persists in the form of other 'monocrops' - hydrocarbons, tourism and (arguably) offshore finance. Economic vulnerability remains a structural characteristic of plantation islands, not just because of narrow specialization and dependence on world market prices for primary products (which have generally been falling), but also because of heavy concentration of ownership of the means of production either in the hands of a local plantocracy or in multinational corporations (Warrington \& Milne, 2007: 411). Migration-wise, such islands are characterized by a history of involuntary immigration of slaves and indentured labour, which has bequeathed a racially structured unequal society. When the economy collapses, mass emigration results; labour becomes the monocrop to be exported. Many of the island states and dependent territories of the Caribbean (and also some in the Indian and Pacific Oceans) conform to this regime of political economy and migration.

Islands as fiefs share some of the historical, economic and migration characteristics of plantation islands. Fief islands are the polar opposite to islands of civilization. They are defined by extreme peripherality and vulnerability compounded by a history of rapacious 
exploitation by local and external elites. Sicily and Haiti are archetypal fief islands, afflicted by a set of structures which are inimical to development - mafia organizations, extreme traditionalism, violence, corruption and illegitimate exercise of power. Irish history before 1921 is also often defined in terms of being a British protestant fiefdom. Wholesale emigration, often under traumatic circumstances (cf. the Irish famine of the mid-1840s), is the accompanying consequence as the only 'way out'.

Next comes the island as fortress; a site for protecting and projecting power. Malta is the exemplar, but there are other cases such as St. Lucia in the eighteenth century, Singapore during the interwar years, and Hong Kong prior to its transfer to China. Colonial and military power are the key to the raison d'être of the fortress island, based on a fortuitous combination of strategic location, maritime and air travel technology (which of course can change), and trade and military routes. According to Warrington \& Milne, the pattern of governance of fortress islands is replete with paradoxes: "economic affluence and vulnerability; competent, benign administration but fractious politics; a cockpit of imperial politics, but a weak sense of domestic interests" (2007: 407). The build-up of the fortress economy usually involves some military in-migration, but then mass emigration (as in post-war Malta) follows when the fortress function wanes.

Entrepôt islands exhibit a clear nodal vocation. Locationally entrepôts benefit from nearness to incoming trade routes, functioning as a semi-detached entry-point for adjacent mainlands; but internal sources of entrepôt success derive from investment finance and entrepreneurial flair, and a regulatory regime that facilitates market transactions by minimizing costs and risks. Warrington \& Milne (2007: 413) quote Singapore, the Channel Islands, the Isle of Man and Mauritius as examples of this island political economy. For others - Barbados, Malta, Ireland - the entrepôt function may take over from other political economies - respectively plantation, fortress or fief. The entrepôt trades on commerce and investment rather on large-scale migration, but a combination of emigration and immigration, especially of wealthy merchants, entrepreneurs and tax exiles, is to be expected.

Finally there are islands of refuge, which are conceived as bulwarks against dominant mainland powers. Cuba (against the USA) and Taiwan (against mainland China) are the classic examples, defining themselves ideologically against the alter ego: socialism against capitalism, democracy against autocracy. They are characterized by migrations of refuge, both in and out.

\section{Islands, Migration and Globalization: Two Scenarios}

Set against the dual background of the current era as both the age of globalization and the age of migration, and with my main geographical reference being the Mediterranean Sea and the adjacent eastern Atlantic, I pull out two research scenarios for islands and migration. 


\section{R. King}

The first focuses on the new and key functions of islands as strategic locations in the geopolitics of irregular migration, especially as regards the movement of 'clandestine' migrants between Africa and Europe. Many migrants seeking to enter Europe are engaged in long and tortuous journeys lasting several months or even years: their origins lie far to the south of the African shore and the target destinations may be countries beyond the southern European coasts and islands. Indeed, as 'transit migrants' involved in 'fragmented journeys', their country of destination may not be determined when they leave home; it may change en route according to opportunities that present themselves; or, indeed, they may never get there but be blocked in some intermediate location (Collyer, 2007: 668). Poor migrants (and not-so-poor migrants, given that irregular migration involves substantial costs of travel and smugglers' fees) are increasingly driven by 'push pressures' to depart from their home countries which are often in political or economic chaos; yet they are confronted by global/European regimes of migration control and border securitization which make entry into 'Fortress Europe' ever more difficult and dangerous. As new routes of 'least resistance' are increasingly sought out by migrants and smugglers, certain islands offer themselves as strategically-located staging-posts and entry-points, especially those which are part of the European Union and yet are close to the 'launching pads' of migration in Morocco, Tunisia, Libya etc. In this new strategic geography of irregular migration, Lampedusa (the tiny outpost island of Sicily and Italy), Malta, and the eastern Canary Islands (especially Fuerteventura) are the most attractive stepping-stones into Europe.

The attractiveness, but also dangers, of islands as key sites in the journeys of irregular migrants are all-too evident when we think of the precise spatialities of migration routes and migration control. Controlling a maritime border is fundamentally different and more difficult than a land border because it requires surveillance of an area (the sea) rather than just a line (Carling, 2007a: 324). Compared to land borders, with their checkpoints at road crossings and airports, and the possibility of erecting physical borders such as fences and walls, sea borders are more open and access can be stealthier, under cover of darkness. 'Search and rescue' zones make it possible, even obligatory, for migrants in overloaded boats who are in mortal danger to be picked up and 'taken in', with the chance that they will not be repatriated. The dangers derive from storms and currents overturning the flimsy boats or driving them off-course, engine failure, poor navigational skills, shortage or absence of life-jackets, inability to swim, as well as the unscrupulous behaviour of smugglers and pilots who may abandon migrants too far from the shore to the peril of those who cannot swim. All this has been amply documented, not so much in academic studies (but see Carling, 2007a), but in a plethora of newspaper and NGO reports ${ }^{7}$.

\footnotetext{
${ }^{7}$ See for example the monthly newsletter of PICUM (Platform for International Cooperation on Undocumented Migrants) which has regular reports and statistics on 'Death at the Border'. Routes and tragedies regularly reported on involve the Greek islands close to the Turkish coast, Sicily and Lampedusa, Malta, and the Canary Islands. The November 2004 Newsletter reported an authoritative estimate that 2,000 migrants drown every year in the Mediterranean trying to cross to Europe - half the world total of migrant deaths at sea. From 2004 on, reports on sea drownings increasingly feature the Canaries. The January 2005 Newsletter carried the following harrowing account: "The Spanish coast guard came across a group of undocumented sub-Saharan migrants in a small boat off the coast of Fuerteventura (Canary Islands) on 23 December. Thirteen were dead and the remaining 30 passengers were rescued. Six of the survivors were in a serious condition. Rescue officials said that the scene on the boat was one of horror because the dead and
} 
Carling (2007a, 2007b) and Collyer (2007) have recently documented the evolving geography and technology of migration control in the Mediterranean and near-Atlantic seas. The imposition by the Spanish authorities, with EU backing, of the SIVE surveillance system (Sistema Integrado de Vigilancia Exterior) across the Gibraltar Strait in 2002 made the short-sea crossing between Morocco and Spain, which for years had been crossed by thousands of Moroccan and other migrants in flimsy pateras (makeshift wooden boats), increasingly less feasible. This had the effect of deflecting the main routes for transit migration between Africa and Europe: eastwards to the stretch of Moroccan coast between the Spanish enclaves of Ceuta and Melilla, with migrants aiming at the coast of Granada and Almería; and south-westwards down the Atlantic coast of Morocco, aiming at Cadiz. Application of SIVE to the entire Andalusia coast then forced migrants even further south and east. Routes developed in the early-mid 2000s from southern Morocco, Western Sahara and Mauritania to the Canaries, initially aimed at Fuerteventura, the closest to the African coast, but then, after a partial introduction of SIVE, to Lanzarote, Gran Canaria and Tenerife. As surveillance intensified off these coasts, longer-distance routes have very recently sprung up, involving the Cape Verde islands far to the south. Meanwhile, far to the east, a new maritime bridgehead opened up for irregular migrants transiting Libya towards Sicily and Malta, the latter a new EU entrant in the 2004 enlargement. The case of Malta will be dealt with in the final section of the paper.

Before that, I turn to the second island research scenario. This harks back to the remarks made earlier about the heuristic value of islands as small-scale laboratories for the analysis of societal processes and interactions, but it also has a contrastive connection with the first scenario just outlined. The first scenario was mainly about poor migrants travelling without papers, searching out viable routes to access rich European countries to find work and improve their lives and those of their family members back home. We saw how some islands have acquired great locational significance in this new migration geography. However, for individuals at the other end of the global wealth spectrum, islands become 'playground spaces', to visit as tourists or on yachts or cruises, to buy second homes (or third or fourth homes...), or even to buy the whole island! The invasion of foreign capital to buy island property sets in motion a process of island gentrification which has been imaginatively documented for the Swedish islands around Gothenburg and Stockholm by Clark et al. (2007), and also for Capri (Mazetti, 2007). According to local estate agents, the Swedish market for property on islands has become 'hysterical', such is the demand (Clark et al., 2007: 483). Meanwhile, on the isle of Capri, whose origins as a holiday playground can be traced back to Roman times, building land costs between 6,000 and 10,000 euros per square metre, depending on the site and the view. These are realestate values comparable to many central-city locations, so that Capri has in effect become a luxury residential district of metropolitan Naples, to which it is connected by fast and frequent hydrofoil services (Mazetti, 2007: 612).

living had to share the boat and some survivors were clutching the bodies. The survivors were suffering from dehydration and hypothermia after their boat had drifted at sea for three days without fuel, food or water". In the February 2006 Newsletter it was reported that, during 2005, 226 undocumented migrants had died crossing to the Canary Islands. 


\section{R. King}

In this role, and very different from the vision of desperate migrants, bedraggled on the shores of Lampedusa or Fuerteventura, islands offer an altogether more romantic image which builds on 'the island' as a constant visual and metaphorical trope of tourism and relaxation. Islands embody unique small spaces where peace and quiet, environmental purity and pristine landscapes and seascapes are especially targeted by rich people, retirees and dreamers who have the wherewithal to relocate there, at least for part of their lives.

All these migration types - rich and poor migrants, short-stayers and long-stayers, tourists and retirees etc. - can be located together on many islands such as Tenerife, Gran Canaria, Majorca, Malta or Cyprus. To a greater or lesser extent, they all interact both with the host society and with each other. To be more categorical, we can recognize the following actor groups in this scenario:

- island-born non-migrants - who are nevertheless profoundly affected by the migration of other islanders, as well as the presence of immigrants;

- $\quad$ internal migrants within an archipelago - these may not be immediately recognizable but may partly contribute to define the boundaries of 'belonging';

- $\quad$ emigrants - who may make regular return visits and continue to see themselves as part of the island community;

- $\quad$ returned migrants - who may have returned temporarily or for good;

- $\quad$ tourists and visitors - ranging from short-stay tourists and cruise-ship passengers to those who have second homes where they may stay for several months a year;

- $\quad$ immigrants from wealthy countries, who may be retirees; and

- $\quad$ immigrants from poor countries - both documented and irregular, including asylumseekers.

The small-island context allows close study of multiple migration processes and their interactions; this is more easily visualized within the insular microcosm where the migration actor-groups listed above live in close geographical (but not necessarily social) proximity to each other.

Several interesting research questions and hypotheses arise. Does the small-scale island society offer a welcoming environment where migrants (of various types) can easily settle, supported by personalized relationships which are easier to develop in a local, informal setting? Or are islands unwelcoming places to outsiders who are seen as potential threats to established social orders and networks (see Baldacchino, 2008b)? Or perhaps some immigrant groups are welcomed, others tolerated, and others rejected? How is the key triangular relationship between islanders, wealthy foreign settlers and poor labour immigrants played out? Are returnees 'intermediaries' between 'natives' and immigrants, 
drawing on their own experiences of migration to broker understanding between the various groups?

As yet, there are very few island-based studies which provide answers to these questions. One exception is Salvà-Tomàs (2002) who has examined the relationship between tourism (largely from Germany and the UK) and labour migration (from Africa and South America) in the Balearic Islands, although his is largely a descriptive economic and demographic analysis, not one based on primary survey or ethnographic data. More theoretically innovative is Bianchi's (2000) study of the 'tourist-worker nexus' in the Canaries. Bianchi problematizes the distinction between tourists and tourist-industry workers by exploring the hybrid category of transient resort workers in the context of emergent patterns of postindustrial mobility in which the boundaries between work, leisure and migration are blurred. "Migrant tourist-workers are thus a distinct [group who] encompass aspects of both travel- and work-related mobilities in so far as they lodge their sense of identity in the pursuit of alternative, transient lifestyles, in which resort work and recreation are integral components" (2000: 122). Although this sociological category is not unique to "holiday islands', the sense of escapism associated with island tourist destinations draws many such tourist-workers to island hot-spots such as San Antonio (Ibiza), Mykonos or Agia Napa (Cyprus), where seasonal and casual jobs as tourist reps, nightclub staff, bar workers, lifeguards etc. are fairly abundant.

\section{The Example of Malta}

Malta epitomizes both the island migration scenarios referred to above: the mixing of different migration actor-groups and types of migration within a small insular space and society; and the role of islands in the new spatial dynamics of clandestine migration into the EU. Of course, no island is 'typical' and Malta's unique geo-historical features must be recognized, notably its extremely high population (for its size) and its harbour of special historical and military importance.

The notion of Malta as 'migration's microcosm' (Anon, 1964) is built on a long and varied historical sequence of migrations affecting the island. Malta's function as an island fortress at the crossroads of the Mediterranean - part of a trio of British imperial defence-posts in the Basin along with Gibraltar and Cyprus - gave the island a rather particular developmental and demographic history. The externalized economic base, on an island with few natural resources and an already-dense population, led to a rate of population increase which ultimately proved unsustainable, especially when the 'fortress economy' started to shrink after Britain's global rundown of its military bases following the Suez debacle in 1956. However, long before the post-war emigration boom, Malta had a tradition of exporting its surplus population, especially within the Mediterranean Basin via its commercial links to prominent port-cities such as Algiers, Tunis, Tripoli (Libya), Marseilles and Constantinople (Istanbul) ${ }^{8}$. Price (1954: 115) estimated that, by 1865, there were 40,000 Maltese living abroad, equivalent to $22 \%$ of the population.

\footnotetext{
${ }^{8}$ An interesting sub-story concerns the Maltese settlers in French colonial Algeria who transplanted to France in the early-mid 1960s in the wake of Algerian independence. Andrea Smith's recent monograph traces the
} 


\section{R. King}

This early migration failed to curtail a population growth rate which remained remarkably high for a European country (albeit a strongly Catholic one ideologically opposed to birth control) until well into the post-war era. According to the 1948 Census, one quarter of completed families had ten or more children, a proportion which dropped to one-fifth in the early 1960s, when average family size stood at six children per completed family. Meanwhile the death and infant mortality rates dropped vertiginously, exacerbating population growth. During the late 1950s and early 1960s, births averaged 8,600 per year, deaths only 2,820 , yielding a net annual increment to the population of nearly 6,000 , or $2 \%$ of the population, very high for a country of Malta's level of development and standard of living (King, 1979: 110-111).

The push factors for Malta's 'great exodus' during the three post-war decades were both demographic (high natural increase) and economic (contraction of the fortress economy), the former stressed by Jones (1973), the latter by Delia (1982). During 1946-74 there was an exodus of 138,000 , equivalent to $44 \%$ of the Maltese population. Four destination countries absorbed these emigrants: Australia (58\%), the United Kingdom (22\%), Canada $(13 \%)$ and the United States (7\%). During the peak years of emigration - the $1950 \mathrm{~s}$ and early 1960 s - the rate approached one in 30 or $3 \%$ per year, the highest emigration rate in the world, according to Jones (1973).

As emigration tailed off during the 1970s, two new migrations appeared: a fairly substantial return migration of Maltese labour migrants (King, 1979; King \& Strachan, 1980), and the immigration of so-called 'sixpenny settlers'. The latter were retired (often early-retired) British nationals, many with a military background, who were attracted to Malta by prior connections (such as wartime service there), its low tax rate (six old pence in the pound, or just 2.5 per cent), the warm and sunny climate, and its 'British' colonial flavour (even after independence). This immigration of British retirees continued into subsequent decades; in the mid-1990s the British High Commission estimated the size of the British population in Malta at 5,000 (Warnes \& Patterson, 1998: 121).

There is, however, a more dramatic and recent story of immigration into Malta. This is associated with the country's entry into the EU in 2004, as well as with the above-noted rerouting of African irregular migrants via Libya as a major new transit country ${ }^{9}$. This new immigration trend was already evident in 2002, when Malta's 'European' vocation, after years of debate and vacillation, had become clear, albeit with residual overtones of ambivalence (Baldacchino, 2002; Mitchell, 2002). During that year, 21 boats deposited

trials and tribulations of this 'double migration'. In Algeria, the Maltese, previously colonized under British rule, were the poorest of the nineteenth-century European settler arrivals and were placed at the bottom of the settler hierarchy. After their transfer to France (they had acquired French citizenship in Algeria) they continued to be made to feel socially inferior and a people in exile, compensated only by their adherence to Maltese social clubs (Smith, 2006).

${ }^{9}$ According to the ICMPD (International Centre for Migration Policy Development, Vienna), this migration to Malta is part of a much wider Libyan-sourced boat migration of around 80,000 people per year, targeted at Sicily and Italy (quoted in Hamood, 2008: 19). Estimates of the total number of transit migrants 'stockpiled' in Libya range from 750,000 to 2 million. The migrants are mainly from adjacent countries in north-east and sub-Saharan Africa. 
1,686 irregular migrants and asylum-seekers on the shores of Malta - a rate of arrival which has remained more or less constant, at around 1,700-2,000 per year, ever since. The main nationalities are Egyptians, Sudanese, Ethiopians, Eritreans and Somalis.

The sea journey to Malta, for which migrants pay agents around US $\$ 1,000-1,200$ (figures for 2003-05: Hamood, 2008: 30), follows an equally perilous and much longer (but cheaper, US\$60-180) overland journey on open trucks through the desert, crossing into Libya via unguarded border points. Ironically, most of the migrants arriving in Malta do not want to be there; their target is Italy and the open European space of the Schengen area. Their arrival in Malta is by mistake: they think, or are told by the pilots, that Malta is Sicily; or they are picked up if in danger by patrol-boats in Malta's extensive search and rescue zone - a vast elongated rectangle which stretches from just off the coast of Tunisia nearly to Crete and which is hugely out of proportion to Malta's size compared to the adjoining countries of Tunisia, Libya, Italy, and Greece (see the map in Texiere (2006: 42). The migrants are then 'trapped' in Malta because the rules of the Dublin convention state that asylum claims must be processed in the country of first arrival, with no onward mobility allowed for claimants, and because Malta (unlike Italy) has no return agreement with Libya (Hamood, 2008: 32-33).

Immigration has rapidly proved to be a challenging and hotly debated issue in Malta, stirring up reactions which can certainly be labelled as xenophobic. Neil Falzon, United Nations High Commissioner for Refugees representative in Malta, has stated:

"There's an ugly xenophobia developing here and the government carries some responsibility for that. It is selling the idea that Malta can't cope. The truth is it has to... The government should be leading the process of integrating [the immigrants] with jobs, education and homes instead of taking part in this national hysteria" (quoted in Jones, 2008).

Although the debate on immigration in Malta is often expressed very simplistically, the underlying issues are complex. Undoubtedly there is a wider trope of 'invasion' which is linked both to claims of smallness, islandness and high population density; and to a 'fortress history' of fear of invasion, which also became apparent in debates surrounding EU accession in 2004 (Baldacchino, 2008b: 14). Immigration discourse is also refracted through historical templates of 'race' and 'nation' in which certain immigrants and visitors (especially tourists, Europeans, Christians) are accepted, whilst others (Africans, Arabs, Muslims) are not. Yet seeing immigration as a threat to Maltese national identity is inherently problematic because of the very nature of the concept of identity - identities, pace Stuart Hall (1996), are always contested, insecure, manufactured, processual, relational ... - and because of the consequent difficulty of pinning down exactly what a Maltese national identity - if it exists - consists of (Abela, 2006; Baldacchino, 2002). Bearing in mind these inherent complexities surrounding the nature of Maltese national and cultural identity, I now proceed to try to analyse the discursive dynamics surrounding immigration more systematically. 


\section{R. King}

The recent influx of irregular migrants challenges Maltese national identity and migration policy in three ways. First, there is the perceived 'intrusion' of migrants of different cultures, religions and skin colours, and mostly single young males, into a society which has generally regarded itself as homogenous, family-centred, staunchly Roman Catholic and socially conservative (yet also, at the same time, progressive towards its own disadvantaged members). But this homogeneity is tinged with an inevitable insecurity about national identity (Baldacchino, 2002, 2009; Mitchell, 2002). Who, exactly, are the Maltese? What are their defining national characteristics, given their proclaimed Phoenician heritage, their unique language, and (yet) their subsequent contact with Arab/North African, Italian and British colonial spheres, and consequent histories of immigration? According to Abela (2006), if there is any common feature of Maltese identity, apart from the obvious attachment to their 'island place', it is the Catholic Church, which provides an overarching umbrella of ontological security for the family of the Maltese people, as well as symbolic visual dominance in the scale of the monumental churches rising over Maltese small towns and villages. Cassar (2000) has shown that, historically, Catholic Christian narratives and imagery have not only played a central role in the construction and maintenance of national identity but also have been deployed to guide debates on morality, welfare and social responsibility - including those relating to migration. Migration links, in both directions, between Malta and Sicily were particularly intense during the sixteenth and seventeenth centuries (Cassar, 2000: 95-120).

Immigrants, therefore, are seen as a potential disruption of this fragile Maltese identity with its unique but beleaguered culture and language. But there are at least two ironies here. The first is to do with the nature of Maltese Catholicism. On the one hand there are very high levels of church attendance and unusually high levels of charity donations to worthy causes, both at home and in the 'Third World'. But when the Third World comes to Malta in the embodiment of dark-skinned immigrants, the charity turns to xenophobia, as noted above. The second irony is the failure to make connections between the Maltese experience of mass emigration and the plight of immigrants arriving in Malta ${ }^{10}$. One further irony connects the previous two, and this is the role of certain liberal Catholic organizations, such as the Emigrants Commission (originally founded to support Maltese emigrants) and the Jesuit Refugee Service in acting as providers of important welfare and support services to immigrants and asylum-seekers ${ }^{11}$.

The second discursive framing of irregular migration and asylum-seekers concerns the question of numbers; the notion that "we can't all live on this small island". It is undeniable that Malta has the highest population density of any EU country: 400,000 on just 316 square kilometres of strategically located but agriculturally infertile limestone

\footnotetext{
${ }^{10}$ Of course, there are differences as well as similarities here. Apologists for not appreciating the parallels would point to the nature of Maltese emigration as a well-organized and sponsored movement within the anglophone world, in contrast to the spontaneous and disorganized arrival of boat migrants.

${ }^{11}$ As Mark-Anthony Falzon (2007) has recently shown, this exemplifies a much wider welfare role that the Catholic Church has long played in Malta. Despite periods of schism between the Church and State - as under Dom Mintoff during the 1970s when elements of a workers' welfare state were put in place - the Church-State symbiosis has been well entrenched in Maltese society (if not in overt politics). Recently, under a new regime of 'welfare pluralism' the Church has been well placed to take on new welfare roles including helping immigrants and asylum-seekers.
} 
rock. Although the annual influx of more than 1 million tourists is welcomed because of the importance of tourism for the economy and because, of course, the tourists go home, the annual arrival of 2,000 'illegal' immigrants who will not, or cannot, return home, is seen as a more vital component in the numbers game. In Malta, it is often pointed out that the impact of 2,000 immigrants on a population of 400,000 is equivalent to the annual arrival of 300,000 boat migrants in Italy or 200,000 in Spain. Or, put another way, the 11,500 refugees and irregular migrants processed since 2002 corresponds to about 1.7 million arriving in the UK, France or Italy (Jones, 2008). A further layer of this discourse reflects Malta's self-perception as a 'less-developed country' in European terms, and therefore ill-equipped to deal with the migrant influx. Here the contrast is drawn with other, more wealthy European countries where it is explicitly acknowledged that migrants have a valuable economic function in the labour market, filling jobs that native workers are unwilling to do, such as in agriculture or construction ${ }^{12}$.

This leads to the third, and by far the most complex, challenge: the policy response. This in turn has two dimensions: internal policy measures for the reception, processing, accommodation and integration of migrants and refugees; and the external policy environment of the EU and bilateral relations with sending and transit countries, notably Libya.

What is clear from the few existing studies of the phenomenon of Malta's 'new immigration' (King \& Thomson, 2008; Spiteri, 2004; Texiere, 2006; Thomson, 2006) is that the country was unprepared for those who, echoing the biblical shipwreck of St. Paul, washed up on the shores of Malta in the early $2000 \mathrm{~s}^{13}$. Although on paper the figures for the eventual confirmation of refugee and humanitarian protection status are rather impressive by southern European standards (Thomson, 2006: 6), the way the irregular immigrants and asylum-seekers have been accommodated has been widely condemned ${ }^{14}$. For up to 18 months (now reduced to 12) they are held in overcrowded and poorlyequipped detention camps (which are former military barracks) under the control of soldiers who are trained in warfare not humanitarian work. Subsequently they can be 'released into the community' which usually means they are transferred to 'open centres' from which they can obtain a work permit and seek work ${ }^{15}$. There are no real policies or measures for integration and welfare beyond those offered by charitable bodies.

\footnotetext{
${ }^{12}$ Of course, the economic utility of migrants in other European countries does not prevent them from being subject to racism and discrimination, or even framed as targets for governmental rhetoric.

${ }^{13}$ This is a process which continues today, with tragic consequences. In late August 2008 reports were filed of 70 migrants, Sudanese and Eritreans, losing their lives in rough sea south of Malta when their flimsy boat foundered on its perilous journey from Libya (see The Guardian, 28 August 2008).

${ }^{14}$ Things came to a head with a violent incident at the Safi barracks detention centre in January 2005, when a peaceful demonstration by the migrant inmates against their inhuman treatment and living conditions was brutally repressed by soldiers and the police (Texiere, 2006: 84-90). More recently, reporting on an EUcommissioned study, the Times of Malta wrote (13 January 2008): "The centres for immigrants are overcrowded, riddled with poor hygiene, arbitrary regimes, deficient healthcare, information and legal systems, and lack of interpreters... Malta's repressive measures to try and stem illegal immigration are dehumanising and ineffective, and will neither stop the migratory flow, nor protect the country's interests".

${ }^{15}$ Conditions in the open centres are little better than in the detention camps. A quote from The Guardian of 30 December 2008: "About half of the 4,000 migrants who have been released from detention live in two cramped, unsanitary open centres which are effectively African ghettos... Railing rust bleeds down the
} 


\section{R. King}

The issue of irregular migration has also had an impact on the domestic political scene, boosting the influence of the right-wing Alleanza Nazzjonali (National Alliance) for whom immigration represents a threat, in their own words, to 'Maltese values of faith, nationhood and family'. Public protests against irregular migration have led to clashes in the main square of the capital Valletta between right-wing campaigners and anti-racist groups. Further rhetorical fuel has been thrown on the fiery debate over immigration by the extremist Imperium Europa group which espouses a white supremacist European credo. Articles and letters in Maltese newspapers further reveal the naïveté of the discussion on immigration, with tired allusions to crime and disease, religious fanaticism and clashes of cultures (Spiteri, 2004). These anti-immigrant movements carry only minimal electoral support, but their voice has enhanced importance in the context of the knife-edge balance of power between Malta's two long-established centrist political parties, the Nationalist Party and the Malta Labour Party (Baldacchino, 2008b).

Malta's external policy challenge involves convincing the EU that it deserves special treatment and assistance due to the disproportionate 'burden' of immigration that it has to bear by virtue of its four undeniable geographical features: small size, dense population, location close to the North African coast, and its huge area of maritime responsibility. At the negotiations for the EU entry, Malta did secure two derogations which reflected a different concern - immigration from other EU countries, such as Italy where there was fear of the immigration of unemployed Sicilians. The two exception clauses were a ban on foreigners purchasing second homes in Malta, and a seven-year moratorium on the free entry of EU workers (with permits only granted in exceptional circumstances for a specific purpose). Less success has been gained in relaxing the rules of the 1990 Dublin Convention, which effectively traps migrants in Malta, against the wishes of the Maltese authorities and of the migrants themselves, who want to move north. And a bilateral agreement with Libya allowing Malta to send irregular migrants back has so far proved elusive, as have requests to the Libyans to control the departure of boats from their shores.

Recent attempts by Italy, Greece, Malta and Cyprus to establish a greater EU commitment to 'burden-sharing' over the issue of Mediterranean 'boat-people' migrants have yielded few concrete results. Winter arrivals in late 2008 on the islands of Lampedusa and Linosa, close to Malta, prompted a strong burst of rhetoric from Italy's interior minister Roberto Maroni; if his pressure on the Libyan leadership, linked to a programme of Italian investment in Libya agreed in August 2008, bears fruit and Gaddafi follows through with the quid pro quo of joint coastal patrols of Libya, then Malta might also 'benefit' from reduced arrivals (Hooper, 2008).

So, does Malta need immigrants? Is there a structural need for migrant workers in the Maltese labour market? One straight answer might be 'Yes', simply because Malta is like

whitewashed walls of Marsa, a dilapidated former school converted into an open centre... More than 1,200 migrants take turn to sleep in bunks and share putrid lavatories and showers. The building is divided into ethnic blocks run by Somalis, Sudanese or West Africans. For the fortunate few it is a stopping point before they find a regular salary to rent more salubrious accommodation. For others, Marsa is a symbol of their frustrated hopes... at least one migrant attempts suicide each month". 
any other developed and regulated market economy that is looking to lower production costs. But labour migration is not an absolutely inevitable accompaniment of capitalist success as the case of Finland - one of the most prosperous countries in the EU but with very few labour immigrants - shows (Bartram 2007). For Malta, opinions and evidence differ; we await a thorough study on this question. Certainly there is 'soft' evidence on the presence of a number of immigrant groups beyond the mainly African asylum-seekers and irregular migrants discussed above. There is a Libyan presence which has its roots in the 1970s when prime minister Dom Mintoff's pro-Libyan stance brought Libyan teachers to Malta to teach Arabic in the local schools. As Libya became even more a pariah state in the wake of the 1988 Lockerbie incident, Libyans continued to have visa-free access to Malta until Malta turned towards Europe in the late 1990s. An older-established but small Indian trader community also contributes to Malta's very embryonic multicultural society (Falzon, 2001). Evidence exists for various East European and Middle Eastern migrants working in construction (men) and the hospitality industry (women), and there are Nigerians in the local football teams (Thomson, 2006: 7-8). But in general Malta has a long way to go before it reaches the degree of immigrant penetration into the labour market that has been achieved in other southern EU countries such as Spain, Italy, Greece and Cyprus (King \& Thomson, 2008).

Coming back to the central theme of this paper, the Maltese case illustrates a fundamental dilemma at the heart of the relationship between small islands and migration: islands tend to be 'good' at emigration, because that has been their livelihood for generations; but 'bad' at coping with new immigration, certainly if the latter is on a large scale proportionate to the island's population. Other factors also help to explain this anomaly. Partly the situation has to do with the asymmetry in the migratory relationship between islands and the rest of the world: 100,000 Maltese migrants distributed between four big countries (Australia, Canada, the USA, Britain) have little visibility there; but even 10,000 immigrants in Malta would have high visibility. Moreover the changing geopolitical situation of Malta also is important, as in the combination of EU membership with its geographical positionality at the 'underbelly' of the Union, close to migrant-source routes.

\section{Conclusion}

This paper has argued for a new generation of island migration studies: one which no longer focuses on emigration, depopulation, island diasporas and return migration, but on islands' new role in global relations and on the changing geopolitics of international migration control. In this conclusion, I revisit some of the key points I have made and try to set them within wider theoretical and methodological debates.

First, I have argued that islands can continue to function as a privileged laboratory for migration studies. As the nature of mobility changes in the 'age of global migration', and as new paradigms reshape the focus of migration researchers in their quest to understand the changing nature and geography of global mobility, the heuristic role of islands as spatial laboratories remains full of (mostly unrealized) potential. This much is consistent 


\section{R. King}

with what I have argued in the past (see King, 1999; also Connell \& King, 1999). But this view should not pass unchallenged, and therefore needs further nuancing and justification.

Clifford Geertz critiqued the 'spatial laboratory' theme in his 'thick description' introduction to his 1973 classic The Interpretation of Cultures. Later works by anthropologists such as Marcus (1995) and Candea (2007) also debate the issue of the relevance of the local, small-scale place or community. Although those authors rarely refer to the specificity of a small island as such a bounded site, what they say has relevance for the island-as-spatial-microcosm approach ${ }^{16}$. Marcus' often-cited essay on the emergence of multi-sited ethnography marked the passage from the traditional imaginary of anthropological fieldwork carried out in a single-site location to a more dynamic ethnography contextualized by the structurings of a larger social order, above all the capitalist world system. Hence 'the local' could only be understood - and researched with reference to observations sited elsewhere in the global system. As tracking strategies he suggested following 'the people' (as in migration and mobility), the 'thing' (as in a commodity chain), the biography (as in life-history studies), or following the metaphor, story or conflict (Marcus, 1995: 106-110).

Second, I have pointed to the new function of islands arising from their strategic location as stepping-stones on routes of irregular migration which are themselves constantly shifting in response to 'official' migration control strategies. We noted how some islands Malta, Lampedusa and the Canaries were specifically mentioned - acquire new salience as critical spaces in the continually changing geography of irregular migration routes from Africa and the Near East to Europe. Sometimes such islands - particularly the larger, more prosperous ones like Sicily, Majorca or Cyprus - are the end-destinations of migrants, but more often they are places en route to somewhere else: liminal spaces where they may quickly pass through, or perch for a while, like migrating birds, or get stuck (as in Malta), unable to move on, yet unwilling to turn back.

The debate on multi-locality launched by Marcus (1995) also allows us to combine in a fruitful way two key approaches to the island-migration nexus. Candea's (2007) rejoinder to Marcus re-emphasized the importance of the 'bounded location' for ethnographic enquiry, either as a single site or as multiple, discrete locations which have their own consistency and meaning - the village, the neighbourhood, the tribal territory or, one might add, the (small) island. On the other hand such 'traditional' anthropological field-sites are also arbitrary locations which function as heuristic devices which, in turn, are not so much 'ideal types' or closed-system spatial laboratories; but, rather, reflect "actually existing instances, whose messiness, contingency, and lack of an overwhelming coherence or meaning serve as a 'control' for a broader object of study" (Candea, 2007: 180) - in our case, migration. Hierarchy of scale becomes important here, as the small, bounded fieldsite might indeed be a small island which functions, like a rural village, as a 'coherent community'; or the island (Malta, Corsica...) might be large enough to be composed of several small communities yet for there still to be present a marked insular identity amongst its inhabitants.

\footnotetext{
${ }^{16}$ It is true that Candea's sympathetic critique of Marcus is based on empirical research in Corsica, but the referent is one village - the 'bounded field-site' - on this rather large island.
} 
Marcus' line of argument fits closely with my alternative suggestion for seeing islands not, in this instance, as semi-closed systems or small-scale laboratories for social research, but as critically placed nodes within much broader dynamics linking wider spatial realms and processes, potentially global in scale. By its very nature, migration links islands to other places; indeed migration is the most obvious exemplification of the need for multi-sited research, since there is always a 'here' and a 'there' involved. This, surely, is the attraction of islands for migration researchers (and the attraction of migration for island researchers).

\section{Acknowledgements}

This paper is based on a keynote lecture to the conference 'Connecting Worlds: Emigration, Immigration, and Development in Insular Spaces', held at Angra do Heroismo, Azores, 2930 May 2008. Thanks to Lucinda Fonseca, Daniela DeBono and Sharon Spiteri for useful discussions around the themes of this paper, and to Island Studies Journal's three anonymous referees for some helpful suggestions which I have tried to respond to. My visits to Malta in 2005 and 2006 were funded by a Social Sciences Small Grant from the Nuffield Foundation (grant SGS/01207/6) which is gratefully acknowledged.

\section{References}

Abela, A.M. (2006) 'Shaping a National Identity: Malta in the European Union', International Journal of Sociology, Vol. 35, No. 4, pp.10-27.

Anon (1964) 'Malta: Migration's Microcosm', International Migration Digest, Vol. 1, No. 2, pp. 211-213.

Apostolopoulos, Y. \& Gayle, D.J. (eds.) (2002) Island Tourism and Sustainable Development: Caribbean, Pacific and Mediterranean Experiences, Westport CT, Praeger.

Baldacchino, G. (2002) 'A Nationless State? Malta, National Identity and the European Union', West European Politics, Vol. 25, No. 4, pp. 191-206.

Baldacchino, G. (2004) 'The Coming of Age of Island Studies', Tijdschrift voor Economische en Sociale Geografie, Vol. 95, No. 3, pp. 272-283.

Baldacchino, G. (2005) 'Islands: Objects of Representation', Geografiska Annaler, Vol. 87B, No. 4, pp. 247-251.

Baldacchino, G. (2007) 'Introducing a World of Islands' in G. Baldacchino (ed.) A World of Islands: An Island Studies Reader, Charlottetown, Canada and Luqa, Malta, University of Prince Edward Island, Institute of Island Studies and Agenda Academic, pp. 1-29.

Baldacchino, G. (2008a) 'Studying Islands: On Whose Terms?', Island Studies Journal, Vol. 3, No.1, pp. 37-56. 
Baldacchino, G. (2008b) 'Immigrants, Tourists and Others from Away: "Come Visit, but Don't Overstay". The Threat of Invasion to Island Societies', Paper to the Conference 'Connecting Worlds: Emigration, Immigration and Development in Insular Spaces', Angra do Heroismo, Azores, 29-30 May 2008.

Baldacchino, G. (2009) 'Pangs of Nascent Nationalism from the Nationless State? Eurocoins and Undocumented Migrants in Malta, Post European Union Membership', Nations and Nationalism, Vol. 15, No. 1, pp. 148-165.

Baldacchino, G. \& Greenwood, R. (eds.) (1998) Competing Strategies of Socio-Economic Development for Small Islands, Charlottetown, Canada, University of Prince Edward Island, Institute of Island Studies.

Baldacchino, G. \& Milne, D. (eds.) (2000) Lessons from the Political Economy of Small Islands: The Resourcefulness of Jurisdiction, Basingstoke, Macmillan.

Bartram, D. (2007) 'Conspicuous by their Absence: Why are there so few Foreign Workers in Finland?', Journal of Ethnic and Migration Studies, Vol. 33, No. 5, pp. 767-782.

Basch, L., Glick Schiller, N. \& Szanton Blanc, C. (1994) Nations Unbound: Transnational Projects, Postcolonial Predicaments, and Deterritorialized Nation-States, New York, Gordon and Breach.

Beck, U. \& Beck-Gernsheim, E. (2002) Individualization: Institutionalized Individualism and its Social and Political Consequences, London, Sage.

Bertram, G. \& Poirine, B. (2007) 'Islands and Political Economy' in G. Baldacchino (ed.) A World of Islands: An Island Studies Reader, Charlottetown, Canada and Luqa, Malta, University of Prince Edward Island, Institute of Island Studies and Agenda Academic, pp. 325-377.

Bertram, G. \& Watters, R.F. (1985) 'The MIRAB Economy in the South Pacific Microstates', Pacific Viewpoint, Vol. 26, No. 3, pp. 497-520.

Bertram, G. (2006) 'The MIRAB Model in the Twenty-First Century', Asia Pacific Viewpoint, Vol. 47, No. 1, pp. 1-14.

Biagini, E. \& Hoyle, B. (eds.) (1999) Insularity and Development: International Perspectives on Islands, London, Pinter.

Bianchi, R. (2000) 'Migrant Tourist-Workers: Exploring the "Contact Zones" of PostIndustrial Tourism’, Current Issues in Tourism, Vol. 3, No. 2, pp. 107-137.

Bourdieu, P. (1986) 'The Forms of Capital' in J.G. Richardson (ed.) Handbook of Theory and Research for the Sociology of Education, New York, Greenwood Press, pp. 241-258. 
Boyle, P., Halfacree, K. \& Robinson, V. (1998) Exploring Contemporary Migration, London, Longman.

Braudel, F. (1972) The Mediterranean and the Mediterranean World at the Time of Philip II, London, Methuen.

Briguglio, L. (1995) 'Small Island Developing States and their Economic Vulnerabilities', World Development, Vol. 23, No. 9, pp. 1615-1632.

Briguglio, L., Archer, B., Jafari, J. \& Wall, G. (eds.) (1996a) Sustainable Tourism in Islands and Small States, Vol. 1: Issues and Policies, London, Pinter.

Briguglio, L., Butler, R.W., Harrison, D. \& Leal Filho, W. (eds.) (1996b) Sustainable Tourism in Islands and Small States, Vol. 2: Case Studies, London, Pinter.

Brookfield, H. (1990) 'An Approach to Islands' in W. Beller, P. d'Ayala \& P. Hein (eds.) Sustainable Development and Environmental Management of Small Islands, Paris, Parthenon, pp. 23-33.

Brunhes, J. (1920) Human Geography, London, Harrap.

Candea, M. (2007) 'Arbitrary Locations: In Defence of the Bounded Field-site', Journal of the Royal Anthropological Institute, Vo. 13, No.1, pp.167-184.

Carling, J. (2002) 'Migration in the Age of Involuntary Immobility: Theoretical Reflections and Cape Verdean Experiences', Journal of Ethnic and Migration Studies, Vol. 28, No. 1, pp. 5-42.

Carling, J. (2007a) 'Migration Control and Migrant Fatalities at the Spanish-African Borders', International Migration Review, Vol. 41, No. 2, pp. 316-343.

Carling, J. (2007b) 'Unauthorized Migration from Africa to Spain', International Migration, Vol. 45, No. 4, pp. 3-37.

Casado-Díaz, M.A., Kaiser, C. \& Warnes, A.M. (2004) 'Northern European Retired Residents in Nine Southern European Areas: Characteristics, Motivations, and Adjustment', Ageing and Society, Vol. 24, No. 3, pp. 353-381.

Cassar, C. (2000) Society, Culture and Identity in Early Modern Malta, Malta, Mireva Publications.

Castles, S. \& Miller M.J. (2003) The Age of Migration, Basingstoke, Palgrave Macmillan.

Clark, E., Johnson, K. Lundholm, E. \& Malmberg, G. (2007) 'Island Gentrification and Space Wars' in G. Baldacchino (ed.) A World of Islands: An Island Studies Reader, 
Charlottetown, Canada and Luqa, Malta, University of Prince Edward Island, Institute of Island Studies and Agenda Academic, pp. 481-512.

Collyer, M. (2007) 'In-between Places: Trans-Saharan Transit Migrants in Morocco and the Fragmented Journey to Europe', Antipode, Vol. 39, No. 4, pp. 668-690.

Connell, J. \& King, R. (1999) 'Island Migration in a Changing World' in R. King \& J. Connell (eds.) Small Worlds, Global Lives: Islands and Migration, London, Pinter, pp. 126.

Connell, J. (1988) Sovereignty and Survival: Island Microstates in the Third World, Sydney, University of Sydney, Department of Geography, Research Monograph, No. 3.

Connell, J. (1994) 'The Cayman Islands: Economic Growth and Immigration in a British Colony', Caribbean Geography, Vol. 5, No. 1, pp. 51-66.

Connell, J. (2007) 'Migration' in G. Baldacchino (ed.) A World of Islands: An Island Studies Reader, Charlottetown, Canada and Luqa, Malta, University of Prince Edward Island, Institute of Island Studies and Agenda Academic, pp. 455-481.

Defoe, D. (1719/1980) Robinson Crusoe, London, Penguin.

Delia, E.P. (1982) 'The Determinants of Modern Maltese Emigration', International Migration, Vol. 20, No.1-2, pp. 11-25.

Dommen, E. \& Hein, P. (eds.) (1985) States, Microstates and Islands, London, Croom Helm.

Falzon, M.A. (2001) 'Origins and Establishment of the Indian Business Community in Valletta', Bank of Valletta Review, No. 24, pp. 73-92.

Falzon, M.A. (2007) 'God Protect me from my Friends: Prelates, Politicians, and Social Welfare in Contemporary Malta', Journal of Mediterranean Studies, Vol. 17, No.1, pp. 4772 .

Felgentreff, C. (1999) 'Spatial Population Mobility as Social Interaction: A Fijian Island's multi-local Village Community' in R. King \& J. Connell (eds.) Small Worlds, Global Lives: Islands and Migration, London, Pinter, pp.255-276.

Geertz, C. (1963) Agricultural Involution: The Process of Ecological Change in Indonesia, Berkeley CA, University of California Press.

Geertz, C. (1973) The Interpretation of Cultures, New York, Basic Books. 
Glick Schiller, N. \& Fouron, G. (1998) 'Transnational Lives and National Identities: The Identity Politics of Haitian Immigrants' in M.P. Smith \& L.E. Guarnizo (eds.) Transnationalism from Below, New Brunswick NJ, Transaction Publishers, pp. 130-161.

Gössling, S. \& Wall, G. (2007) 'Island Tourism' in G. Baldacchino (ed.) A World of Islands: An Island Studies Reader, Charlottetown, Canada and Luqa, Malta, University of Prince Edward Island, Institute of Island Studies and Agenda Academic, pp.429-453.

Gössling, S. (ed.) (2003) Tourism and Development in Tropical Islands: Political Ecology Perspectives, Cheltenham, Edward Elgar.

Guarnizo, L.E. (1994) 'Los 'Dominican Yorks': The Making of a Binational Society', Annals of the American Academy of Political and Social Science, Vol. 533, pp. 70-86.

Guarnizo, L.E. (1997) 'The Emergence of a Transnational Social Formation and the Mirage of Return amongst Dominican Transmigrants', Identities, Vol. 4, No. 2, pp. 281322.

Hamood, S. (2008) 'EU-Libya Cooperation on Migration: A Raw Deal for Refugees and Migrants?', Journal of Refugee Studies, Vol. 21, No. 1, pp. 19-42.

Hall, S. (1996) 'Who needs Identity?' in S. Hall \& P. Du Gay (eds.) Questions of Cultural Identity, London, Sage, pp.1-17.

Hay, P. (2006) 'A Phenomenology of Islands', Island Studies Journal, Vol. 1, No. 1, pp. $19-42$.

Hintjens, H.M. \& Newitt, M.D.D. (eds.) (1992) The Political Economy of Small Tropical Islands: The Importance of Being Small, Exeter, University of Exeter Press.

Hooper, J. (2008) 'Thousands more Migrants reach Italy's Shores', The Guardian, 30 December 2008, p.17.

Itzigsohn, J., Cabral, C.D., Medina, E.H. \& Vazquez, O. (1999) 'Mapping Dominican Transnationalism: Narrow and Broad Transnational Practices' Ethnic and Racial Studies, Vol. 22, No. 2, pp. 316-339.

Jones, A. (2008) 'Malta: Where Hysteria is no Answer to the Plight of Refugees', The Guardian, 30 December 2008, p.17.

Jones, H.R. (1973) 'Modern Emigration from Malta', Transactions of the Institute of British Geographers, Vol. 60, pp.101-120.

Kaye, R. (2001) “"Blaming the Victim”: "An Analysis of Press Representation of Refugees and Asylum-seekers in the United Kingdom in the 1990s' in R. King \& N. Wood (eds.) 
Media and Migration: Constructions of Mobility and Difference, London, Routledge, pp. 53-70.

King, R. (1979) 'Post-war Migration and Return Migration in Malta', European Demographic Information Bulletin, Vol. 10, No. 3, pp. 108-128.

King, R. (1993) 'The Geographical Fascination of Islands' in D.G. Lockhart, D. DrakakisSmith \& J.A. Schembri (eds.) The Development Process in Small Island States, London, Routledge, pp.13-37.

King, R. (1996) 'Migration in a World Historical Perspective' in J. van den Broeck (ed.) The Economics of Labour Migration. Cheltenham, Edward Elgar, pp. 7-75.

King, R. (1999) 'Islands and Migration' in E. Biagini \& Hoyle, B. (eds.) Insularity and Development: International Perspectives on Islands, London, Pinter, pp. 93-115.

King, R. (2002) 'Towards a New Map of European Migration’ International Journal of Population Geography, Vol. 8, No. 2, pp. 89-106.

King, R. (2007) A History of Migration, London, Marshall Editions.

King, R. (2008) Review of G. Baldacchino (ed.) A World of Islands: An Island Studies Reader, Island Studies Journal, Vol. 3, No. 2, pp. 131-134.

King, R. \& Connell, J. (eds.) (1999) Small Worlds, Global Lives: Islands and Migration, London, Pinter.

King, R. \& Strachan, A. (1980) 'The Effects of Return Migration on a Gozitan Village', Human Organization, Vol. 39, No. 2, pp. 175-179.

King, R. \& Thomson, M. (2008) 'The Southern European Model of Immigration: Do the cases of Malta, Cyprus and Slovenia fit?', Journal of Southern Europe and the Balkans, Vol. 10, No. 3, pp. 265-291.

Lawrence, D.H. (1926/1982) The Man Who Loved Islands, London, Penguin.

Lockhart, D.G. \& Drakakis-Smith, D. (eds.) (1997) Island Tourism: Trends and Prospects, London, Pinter.

Lockhart, D.G., Drakakis-Smith, D. \& Schembri, J.A. (eds.) (1993) The Development Process in Small Island States, London, Routledge.

Lowenthal, D. (1992) Small tropical islands: a general overview, in H.M. Hintjes \& M.D.D. Newitt (eds.) The Political Economy of Small Tropical Islands, Exeter, Exeter University Press, pp. 18-29. 
Marcus, G. (1995) 'Ethnography in/of the World-system: The Emergence of Multi-Sited Ethnography', Annual Review of Anthropology, Vol. 24, No. 1, pp. 95-117.

Mazetti, E. (2007) 'Radiografia di un Organismo Geografico Complesso: L’Isola di Capri', Rivista Geografica Italiana, Vol. 114, No. 4, pp. 593-619.

McCall, G. (1994) 'Nissology: The Study of Islands', Journal of the Pacific Society, Vol. 17, No. 2-3, pp. 1-14.

McCall, G. (1996) 'Clearing Confusion in a Disembedded World: The Case for Nissology', Geographische Zeitschrift, Vol. 84, No. 2, pp. 74-85.

Mitchell, J. (2002) Ambivalent Europeans: Ritual, Memory and the Public Sphere in Malta, London, Routledge.

Price, C.A. (1954) Malta and the Maltese: A Study in Nineteenth-Century Migration, Melbourne, Georgian House.

Ratter, B.M.W. \& Sandner, G. (1996) 'Small Islands, Large Questions', Geographische Zeitschrift, Vol. 84, No. 2, pp. 63-66.

Ravenstein, E.G. (1885) 'The Laws of Migration - I', Journal of the Royal Statistical Society, Vol. 48, No. 2, pp. 167-235.

Ravenstein, E.G. (1889) 'The Laws of Migration - II', Journal of the Royal Statistical Society, Vol. 52, No. 2, pp. 241-305.

Read, R. (2004) 'The Implications of Increasing Globalization and Regionalism for the Economic Growth of Small Island States', World Development, Vol. 32, No. 2, pp. 365378.

Robertson, G. (2007) 'Resources for Island Studies' in G. Baldacchino (ed.) A World of Islands: An Island Studies Reader, Charlottetown, Canada and Luqa, Malta, University of Prince Edward Island, Institute of Islands Studies and Agenda Academic, pp. 539-577.

Salvá-Tomás, P.A. (2002) 'Tourist Development and Foreign Immigration in the Balearic Islands', Revue Européenne des Migrations Internationales, Vol. 18, No. 1, pp. 87-101.

Schneider, P. \& Schneider, J. (1976) Culture and Political Economy in Western Sicily, New York, Academic Press.

Semple, E.C. (1911) Influences of the Geographic Environment, London, Constable.

Sheller, J. \& Urry, J. (2006) 'The New Mobilities Paradigm', Environment and Planning A, Vol. 38, No. 2, pp. 207-226. 
Skeldon, R. (2006) 'Interlinkages between Internal and International Migration and Development in the Asian Region', Population, Space and Place, Vol. 12, No. 1, pp. 1530 .

Smith, A. (2006) Colonial Memory and Postcolonial Europe: Maltese Settlers in Algeria and France, Minneapolis MN, University of Indiana Press.

Spiteri, S. (2004) Treasure Island: A journey of Self-Discovery with the Help of Asylumseekers and Refugees in Malta, Cardiff, University of Cardiff, School of Journalism, MA dissertation.

Texiere, F. (2006) At the Gate of Fortress Europe: Irregular Immigration and Malta. Rennes, France, Institute for Political Studies Sciences Po Rennes (thesis).

Thomson, M. (2006) Migrants on the Edge of Europe: Perspectives from Malta, Cyprus and Slovenia, Brighton, University of Sussex, Sussex Migration Working Paper, 35.

Urry, J. (2000) Sociology beyond Society: Mobilities for the 21st Century, London, Sage.

Vertovec, S. \& Cohen, R. (eds.) (1999) Migration, Diasporas and Transnationalism, Cheltenham, Edward Elgar.

Vidal de la Blache, P. (1926) Principles of Human Geography, London, Constable.

Vine, D. (2004) 'War and Forced Migration: The United States Military Base at Diego García', International Migration, Vol. 42, No. 3, pp. 111-143.

Warnes, A.M. \& Patterson, G. (1998) 'British Retirees in Malta: Components of the Crossnational Relationship', International Journal of Population Geography, Vol. 4, No. 3, pp.108-128.

Warrington, E. \& Milne, D. (2007) 'Island Governance' in G. Baldacchino (ed.) A World of Islands: An Island Studies Reader, Charlottetown, Canada and Luqa, Malta, University of Prince Edward Island, Institute of Island Studies and Agenda Academic, pp. 379-427.

Williams, A.M. \& Fonseca, M.L. (1999) 'The Azores: Between Europe and North America' in R. King \& J. Connell (eds.) Small Worlds, Global Lives: Islands and Migration, London, Pinter, pp. 55-76. 